\title{
Exakte Messung der Grundwassererneuerung
}

\section{von Martin Schwind}

Die Frage nach der Menge des Niederschlags, die nicht oberflächlich abfließt, auch nicht von der Vegetation zurückgehalten oder verdunstet wird, sondern in das Grundwasser gelangt, ist sehr alt. Die Infi-. ltrationstheorie behauptere. "Alles Wasser, welches in der Erde ist, rührt her vom Regenwasser". Die" Kondensationstheorie setzte dem entgegen: "Kein Wasser des Erdbodens rührt her vom Regenwasser." In diesen Extremen hat man diese Frage noch vor 80 Jahren zu beantworten versucht (O. Volger, 1877). Schon K. Keilhack spricht 1902 davon, daß "beide Theorien unzweifelhaft ihre Berechtigung haben."

Es ist heute keine Frage mehr, daß die Grundwasserbildung (Grundwassererneuerung) ganz wesentlich abhängt von der Durchlässigkeit der verschiedenen Bodenarten. Ein Sandboden läßt mehr Wesser in das Grundwasser durch als ein Lehmboden Reinhold Tüxen hat nun mit Hilfe des Lysimeters ein Verfahren entwickelt, mit dem die Wassermengen, die große Bodentiefen erreichen, exakt ermittelt werden können.

Tüxen ist Pflanzensoziologie; sein Interesse gilt also der Frage, in welchem Grade die Grundwassererneuerung von den Pflanzengesellschaften beeinflußt wird. Er geht von der Tatsache aus, daß ein offener Boden, der monatelang schwach oder gar nicht bewachsen ist, viel weniger Wasser verbraucht als ein Boden, der von Wiese oder Wald bestanden ist, und er hat seit 1957 jenen Anteil der Niederschläge, der durch Vegetation und Boden hindurch bis in das Grundwasser gelangt, mit Hilfe des Lysimeters em. pirisch gemessen. Voraussetzung für zuverlässige Ergebnisse ist aber, daß die Lysimeter in gewachsenen Boden eingebaut werden. Ein Lysimeter, das rachträglich mit einer beliebigen Bodenart ohne oder auch mit Pflanzenbestand gefüllt wird, ergibt keine Werte, die verwendbar sind; denn in solchem Falle ist das. natürliche Bodengefüge gestört und die Vegetation entspricht nicht der Wirklichkeit. Die an 10 Lysime tern im Abflußjahr 1958 vorgenommenen Messungen ergaben die in der Tabelle aufgeführten Werte.

Grundwasserspende der Lysimeterstationen in \% des Niederschlags, 1958

\begin{tabular}{|c|c|c|c|}
\hline Station & Natürliche potentielle Vegetation & Bewuchs & Grundwasserspende in $\%$ \\
\hline 1 & Fageto-Quercetum typicum & Heide & 85 \\
\hline 2 & do. & Winter-Roggen & 66 \\
\hline 3 & do. & Kartoffeln & 66 \\
\hline 4 & do. & Winter-Roggen & 63 \\
\hline 5 & do. & Kartoffeln & 61 \\
\hline 6 & do. & Sommer-Getreide & 54 \\
\hline 7 & Querceto-Carpinetum asperuletosum & Winter-Roggen & 29 \\
\hline 8 & do. & Sommer-Getreide & 26 \\
\hline 9 & Fraxineto-Ulmetum & Winter-Weizen & 25 \\
\hline 10 & do. & Weide & 05 \\
\hline
\end{tabular}

Diese Ergebnisse, die natürlich noch nicht verallgemeinert werden können, zeigen deutlich, wie stark

1) Schwind, M. : Die Oberflächenformen des Mittelsächsischen Berglandes. Leipzig 1933. S. $20 \mathrm{ff}$.

2) Tüxen," Reinhold : Lysimeter in Pflanzengesellschaften. In : Mitteilungen der floristisch-soziologischen Arbeitsgemeinschaft, N. F. Heft 6/7. Stolzenau/Weser 1957. S. 335. 
die Grnudwassererneuerung von dem Bewuchs des Bodens abhängt. Umekehrt zeigen sie auch, wie der : oberflächliche Abfluß je nach dem Bewuchs des Erdbodens wechselt. Für die Beurteilung des oberfläc。 hlichen Abflusses und für die Bewertung der Bodenerosionsgefahr lassen sich mit Hilfe der Lysimeter exakte Grundwerte finden, vorausgesetzt daß diese Meßapparate in genügender Anzahl eing ebaut werden.

Die von Tüxen durchgeführten Beobachtungen haben unbeabsichtigt noch zu einem weiteren Ergebnis geführt. Die chemicche Untersuchung des durch die Lysimeter aufgefangenen Wassers ergab, daß überall dort, wo der Bauer mit starker Stickstoffdüngung arbeitet, dem Grundwasser ein viel zu hoher Anteil an Nitraten (No3) zusickert. Im allgemeinen werden Brunnen mit einem Gehalt von $50 \mathrm{mg}$ No 3 pro Liter Wasser polizeilich geschlossen. Die im Grundwasser der gedüngten Äcker vorgefundenen Nitrate sind z. T. ein Mehrfaches von $50 \mathrm{mg} / \mathrm{l}$. Mit anderen Worten: die Lysimetermessungen sind zugleich eine Kontrolle für die Volksgesundheit. Je stärker die Landwirtschaft ihre Erträge durch Anwendung von Düngemitteln steigert, desto höher wird die Gefahr der Versuchung des Grundwassers. Hier erwächst für die kulturgeographische und hydrologische Forschung eine verantwortungsvolle Aufgabe.

\section{- Fumio Tada zum 60 Geburtstag - 地下水形成量の精密測定*) : マルチン シュヴント}

降水量のうち，表面流出量・植生消費量・蒸発量 を引いた地下水に供給される量の闍題は，非常に古 い問題である11. 渗透説によれば，地中の水分はす ベて雨水に帰因するものであり，凝結説によれば， 雨水による地下水は存在しない。この三つの極端な 説によつて，約 80 年前までは，この問題に解答を与 えようと努力していた（O. Volger，1877)．1902年 にいたり K. Keilhack によつてこの二つの説の正当 性は疑わしいとせられた。

今日では，地下水の形成に土壌の透水性か関係し ていることに疑問の余地はない，砂質の土壌は，粘 土質土缺よりも多量の地下水を存在させる. Reinhold Tüxen は地下深部に達した水量を正確に測定 することのできるリジメーター2゙を使用して研究を 深めた。Tüxen は植物社会学者である。したがつ て彼の関心は地下水形成量が植物社会によつて影響 される度合に向けられている，彼は，長期間ほとん ど植生のなかつた裸地が，森林・草地の土壤よりも 水消費量がずつと少ないという事実より出発し。
1957年以降の降水量のうち植生・土壤を通過して地 下水に達する割合をリジメーターを使用して実側し た、しかしながら，信頼すべき結果を得るためには リジメーターが自然のままの土塞にすえつけられる ことが前提になる.リジメーターの中にあとから任 意の土壌と植物を入れたのでは利用価值のある值は 得られない, 土㙵構成は破壊され，植物も現実の 姿とことなる．10籄のリジメーターを使用して1958 年に行われた測定の結果は下表の通りである.

この結果を一般化することはもちろんできないが。 地下水形成に作物の種類がいかに大きく関係してい るかが判る. 同時にそれは表面流出量が植物の種類 によつていかに異なるかを示している。したがつて。 もしこの測定器が大量に作られるならば，表面流出 量の測定によつて，土壌侵蝕の危険度について正確 な資料を得ることができるであろう。Tüxen によ つて行われたこの観測は，もう一つ予期しない結果 を生んだ。すなわち、リジメーターにとらえられた 水の化学分析の結果，農民が窒素肥料を多量に使用

*) 本編を多田文男教授還暦記念に捧げる。 
降水が地下水になる割合（1958）

\begin{tabular}{|c|c|c|c|}
\hline 地 点 & 自然植生 & 作＼cjkstart物 & $\begin{array}{r}\text { 地下水の割合 } \\
(\%)\end{array}$ \\
\hline 1 & ブナーカシ型 & 荒＼cjkstart地 & 85 \\
\hline 2 & " & 冬ライ麦 & 66 \\
\hline 3 & ” & ジャガイモ & 66 \\
\hline 4 & ” & 冬ライ麦 & 63 \\
\hline 5 & ” & ジャガイモ & 61 \\
\hline 6 & " & 夏＼cjkstart麦 & 54 \\
\hline 7 & カシーシデ型 & 冬ライ麦 & 29 \\
\hline 8 & " & 夏 麦 & 26 \\
\hline 9 & トネリコーニレ型 & 冬小麦 & 25 \\
\hline 10 & ” & 牧草 & 05 \\
\hline
\end{tabular}

するところではどこでも，高い硝酸根の含有がみら れた. 1 リットル $50 \mathrm{mg}$ 当りの含有量をもつ井戸は 警察の命令によつて閉鎖される，施肥の行われる耕 地のうちには， $50 \mathrm{mg} / \mathrm{l}$ の何倍もの值を示すものも ある、すなわちリジメーターは公衆衛生管理にも使 用することができる．農業の集約化が進んで肥料の 使用量が増すほど地下水の污染はひどくなるのであ るからここに文化地理学と水文学にとつて大切な 課題が生ずる。（鈴木秀夫訳） 